Review

\title{
Use of Laser Systems in Orthodontics
}

\author{
Kevser Kurt Demirsoy' (D), Gökmen Kurt² (D)
}

'Department of Orthodontics, Faculty of Dentistry Nevşehir Hacı Bektaş Veli University, Nevsehir, Turkey

2Department of Orthodontics, Bezmialem Vakıf University School of Dentistry, İstanbul, Turkey

Cite this article as: Kurt Demirsoy K, Kurt G. Use of Laser Systems in Orthodontics. Turk J Orthod 2020; 33(2): 133-40.

\begin{abstract}
Laser systems have been used in the practice of dentistry for $>35$ years. Laser systems have so many advantages, such as increase patient cooperation, reduce the duration of treatment time, and help the orthodontists to enhance the design of a patient's smile to improve treatment efficacy, and the success of orthodontic treatments can also be improved by diminishing the orthodontic pain and the discomfort of the patients. Laser systems also have some disadvantages, such as cost, large space requirements for some types, and high-risk potential for physician and patient if not used at the appropriate wavelength and power density, that is why before incorporating lasers into clinical practice, the physician must fully understand the basic science, safety protocol, and risks associated with them. Lasers have many applications in orthodontics, including accelerating tooth movement, bonding and debonding processes, pain reduction, bone regeneration, etching procedures, increase mini-implant stability, soft tissue procedures (gingivectomy, frenectomy, operculectomy, papilla flattening, uncovering temporary anchorage devices, ablation of aphthous ulcerations, and exposure of impacted teeth), fiberotomy, scanning systems, and welding procedures. In reviewing the literature on the use of laser in orthodontics, many studies have been conducted. The purpose of the present study was to give information about the use of laser in the field of orthodontics, the effects of laser during the postoperative period, and its advantages and disadvantages and to provide general information about the requirements to be considered during the use of laser.
\end{abstract}

Keywords: Dentistry, laser, orthodontics

\section{INTRODUCTION}

Laser (light amplification by stimulated emission of radiation) is a term involving the concepts of light that is amplified by stimulated emission. Laser system basically consists of three components, such as the laser medium (gain medium), the pump source, and the optical cavity or optical resonator. The laser medium is the active element, and the medium determines the wavelength of the laser. The pump source stimulates the laser medium until the light energy is emitted. The optical cavity is a compartment of mirrors that contain the laser medium. The laser optical resonator amplifies the light energy that is released from the gain medium as reflected by the mirrors (fully glazed on one side and partly glazed on the opposite side of the media) back onto itself, where it may be amplified by stimulated emission before exciting the cavity (1). The generated beam of light is the laser beam.

\section{Laser Beam Characteristics}

Laser light differs from normal light with some features. These are the following:

- Laser light is monochromatic, meaning of one color and one wavelength.

- Laser light waves all travel in the same direction, without diffusion (collimated). It is possible to reach distant areas that are difficult to reach with other tools according to the feature of laser beam that travels as a single line without diffusion.

- Same phased photons that generate the light (coherent); laser light has the potential of constructive, as well as descriptive, interference as in radio waves and sound waves. Light wave consists of the spread out of photons 
with different amplitudes, wavelengths, and frequencies (incoherent feature) according to the theory of electromagnetic wave. Laser is a light wave with the same amplitude, frequency (single frequency-single color), and temporal distribution. These point out the coherent features of laser (2).

The history of laser dates back to 1996. Laser has become the agenda with Albert Einstein's theory of propagation of light and the concept of stimulated emission in 1946, is developed with the first indication of induced radiation by W.E. Rutherford in 1947, and the discovery of the MASER system that the only difference from laser is invisible by Charles $\mathrm{H}$. Townes in 1951 and Theodore Maiman realized the first working laser based on ruby crystal (Hughes Research Laboratory) (1). The use of lasers in the medical field occurs in the 1970s. After the beginning of oral surgeons using carbon dioxide $\left(\mathrm{CO}_{2}\right)$ laser on soft tissue in the 1980 s and specifically the production of the first laser to be used in dentistry, many innovations and developments have been followed up until now. The Food and Drug Administration approved the use of erbium laser on hard tissue in 1997 and the use of the first diode laser on soft tissue after 1 year (3).

\section{Classification of Lasers}

As there are many types of lasers used in dentistry and the medical field, it is usual to classify laser devices according to their active material. Lasers are classified into four types based on the type of laser medium used as follows:

- $\quad$ semiconductor lasers (diode laser)

- gas lasers

- $\quad$ solid-state lasers

- fiber lasers (4).

The clinical use of low-level laser therapy (LLLT) in different active environments is realized by different wavelengths measured as nanometers $(\mathrm{nm})$. The frequently used types of low-level lasers and wavelengths are as follows:

\section{- $\mathrm{He}-\mathrm{Ne}: 633 \mathrm{~nm}$ \\ - InGaAIP: 633-700 nm \\ - GaAlAs (gallium-aluminum-arsenide): 780-890 nm \\ - GaAs: $940 \mathrm{~nm}$.}

In LLLT applications, there are too many factors that determine the impact of the laser beam onto the tissue. One of them is the range of the level and the duration of the effect of the used laser. Lasers with different wavelengths and levels of range have various effects on the tissues (Table 1).

\section{Laser-Tissue Interaction}

The three main effects of lasers on the tissues are as follows:

1. photothermal effects: ablation of tissues with vaporization

2. photochemical effect: the biostimulation effect created by increasing the production of ATP

3. photoacoustic effect: dehydration, burning, and carbonization effects (5).

The factors that determine the effect of the laser beam on the tissues are the following:

a) the biological properties of the tissue (absorption power, blood circulation, minerals and water content, and tissue density)

b) the characteristics of the laser (wavelength, energy density, exposure time, continuous or pulsed, maximum pulse energy, with or without contact (contact or non-contact), and the average of pulse repetition (6).

Laser beam leads to chemical changes or thermal effects on the tissues. We can classify these thermal effects as warming $\left(37^{\circ}-\right.$ $\left.60^{\circ}\right)$, coagulation $\left(60^{\circ}-90^{\circ}\right)$, protein denaturation $\left(90^{\circ}-100^{\circ}\right)$, vaporization $\left(100^{\circ}\right)$, tissue carbonization $\left(125^{\circ}-150^{\circ}\right)$, and fast cutting $\left(>125^{\circ}\right)$. These effects on the tissue depend on the low or high level of the laser (7).

\section{USE OF LASER IN ORTHODONTICS}

The orthodontic treatment process is a long and challenging process for both the patient and the physician. Too many complications may occur in the dentoalveolar complex proportionally with the prolonged treatment duration. Laser systems are used in many fields of orthodontics practice to prevent or reduce these types of complications.

\section{Effects of Laser Systems on Orthodontic Tooth Movement}

Many studies have been conducted to accelerate the orthodontic tooth movement. Guram et al. (8) applied low-level GaAIAs diode laser $\left(810 \mathrm{~nm}, 5 \mathrm{~J} / \mathrm{cm}^{2}\right)$ on 20 simple Class I bimaxillary protrusion patients to investigate orthodontic tooth movement duration and pain perception. According to the result of the study, there was a statistically significant decrease in the rate of canine retraction in the laser group compared with the control group, and pain experience was also statistically significant for the first 2 days of orthodontic treatment. As a result, it was underlined that the laser therapy is a useful procedure on orthodontic tooth movement and LLLT can reduce the fixed orthodontic treatment timing. In an in vitro study that aimed to compare the effects of

Table 1. The effect of lasers of different wavelengths and dose ranges on the tissues.

\begin{tabular}{|lcccc|} 
Area of use & Type of laser & $\begin{array}{c}\text { Wavelength } \\
\boldsymbol{X}(\mathbf{n m})\end{array}$ & $\begin{array}{c}\text { Dose range } \\
\left(\mathbf{J} / \mathbf{c m}^{2}\right)\end{array}$ & Effect \\
\hline Acceleration of tooth movement (18) & GaAlAs & 810 & $7-9$ & $\begin{array}{c}\text { Increased macrophage response and proliferation } \\
\text { Increased phagocytic activity of neutrophils }\end{array}$ \\
Bone regeneration (32) & Diode & 780 & 10 & Increased bone formation \\
Condylar growth (39) & KIO3 & 630 & 56 & Reduction in tooth enamel \\
Roughening the surface of the enamel (49) & Er:YAG & 2940 & 8 & Increased osseointegration \\
Mini-implant stability (56) & GaAlAs & 808 & 90 & \\
\hline
\end{tabular}


LLLT, low-intensity pulsed ultrasound (LIPUS), and their combination on bone remodeling during orthodontic tooth movement in rats, there were four groups: the first group was irradiated with $940 \mathrm{~nm}$ diode laser, the second group with LIPUS, and the third group with a combination of both LLLT and LIPUS. The fourth group was used as the control group. It was revealed that the amount of tooth movement and the histological bone remodeling were significantly greater in the treatment groups than in the control group. Among the treatment groups, the combination group was the highest, and the LIPUS group was the lowest. As a result, the use of LLLT and LIPUS can upregulate tissue gene expressions, increase orthodontic tooth movement, and improve bone remodeling (9). Hasan et al. (10) found a statistically significant difference between the two groups (LLLT used and control groups) in the overall treatment time and the leveling and alignment improvement percentage at T1 (after 1 month of treatment commencement) and T2 (after 2 months). Fujita et al. (11) reported that low-dose laser application accelerates the tooth movement and osteoclast genesis on the pressure side of the bone by stimulating the stimulating factor of RANK/RANKL and c-fmc/macrophage colony. The stimulation mentioned here is the biostimulation caused by the application of low-level laser. However, there are opinions advocating that LLLT is not an effective method of increasing the speed of tooth movement. In the review conducted by Long et al. (12), LLLT, corticotomy, electric current, pulsed electromagnetic fields, and dentoalveolar or electromagnetic dental or periodontal distraction were compared in six fields (movement rate, movement time of the tooth to the desired distance, anchorage loss, periodontal health, pulp vitality, and root resorption) according to the effect on the speed of tooth movement. While corticotomy was found to be an effective and safe method for accelerating the amount of tooth movement compared with the other methods, it was stated that LLLT is not an effective method for increasing the speed of tooth movement.

\section{Biostimulation and LLLT}

Biostimulation is the use of low-energy laser beam on the tissues to achieve the biological effect. Basically, it is used in wound healing and in reducing pain. The laser application giving lowdose energy up enough to increase the temperature of applied tissue not more than the normal body temperature $\left(36.5^{\circ} \mathrm{C}\right)$ is described as "low-dose laser therapy" (13). The most well-known theory explaining the action mechanism of therapeutic lasers is photochemical theory. According to this theory, the light is absorbed by specific molecules and is followed by some of the biological chain of events. These photoreceptors are endogenous porphyrins and molecules on the respiratory chain and increase the ATP production (14).

\section{Biological Effects of LLLT}

The biological effects of LLLT are the following:

1. induces the release and synthesis of beta-endorphin

2. increases the production of cortisol (cortisol is the front molecule of cortisone and allows the body to fight stress caused by trauma or disease)

3. increases ATP production
4. increases both DNA functions and protein synthesis ultimately

5. neurotransmission is easy with the increase in the levels of serotonin and acetylcholine

6. mitochondrial activity is stimulated by cell replication

7. the modulation of macrophages, fibroblasts, and other cells occurs

8. cell membrane potential is regulated by $\mathrm{Na}, \mathrm{Cl}$, and $\mathrm{K}$ ions

9. cytokines and other chemicals that accelerate the cellular communication are released

10. arterial microcirculation increases

11. edema decreases with the increase in venous and lymphatic flow

12. inflammation decreases with the increase of leukocytes involved in phagocytosis

13. faster cell division, epithelial growth, and collagen formation are provided

14. minimal scar and decreased keloid formation occur (5).

\section{Reduction of Postoperative Pain}

It is a known fact that postoperative pain occurs within 2-4 days following the application of orthodontic force. The relationship between the degree of force applied and pain still remains unanswered. It has been reported by many researchers that LLLT application provides an analgesic effect in various therapeutic and clinical practices (15). A study where 40 patients who were scheduled to receive orthodontic treatment were randomly divided into the laser group (810-nm gallium-aluminum-arsenic diode laser in continuous mode with the power set at $400 \mathrm{~mW}$ and $2 \mathrm{~J} \cdot \mathrm{cm}^{-2}$ ) and control group was analyzed and found that the application of LLLT appears to reduce the pain and sensitivity of the tooth and gingiva associated with orthodontic treatment. Interestingly, the effect also extended to the contralateral side in the trigeminal region, indicating that LLLT treatment may have some degree of bilateral effects within the orofacial region (16). According to the results of a randomized clinical trial, a single dose of LLLT (940-nm aluminum-gallium-arsenide [Al-Ga-As] diode laser set on continuous mode with the power set at 100 $\mathrm{mW}$ ) considerably decreased postoperative pain accompanying the placement of super-elastic NiTi wires for initial alignment and leveling (17). The laser type that is often used to reduce the pain level in orthodontic treatment is GaAlAs lasers. The mechanism under the analgesic effect of laser application is not exactly known, but some researchers thought that laser application has neuropharmacological effects on the synthesis, release, and metabolization of some mediators, such as serotonin and acetylcholine in the central level and histamine and prostaglandin in the peripheral level (18).

\section{Effect on Bone Regeneration}

Orthodontic treatment includes many regeneration techniques with too many bones and support tissues, such as rapid maxillary expansion, distraction osteogenesis, and condylar adaptation. In vivo studies showed that the LLLT positively affects wound healing by accelerating bone regeneration, stimulating trabecular osteoid tissue formation, increasing vascularization, modulating cell functions, and supporting the acceleration of bone callus reaction (19). In a study examining 
the effects of diode laser use on rapid maxillary expansion, 27 individuals between the ages of 8 and 12 years were separated into two groups with and without laser application. In the laser-applied group, diode laser was applied to 10 points around the mid-palatal suture, and the changes have been followed with occlusal radiographs used for density evaluation. In conclusion, it has been found that there is an effective opening in the mid-palatal suture with LLLT and bone regeneration and healing were accelerated (19). Moawad et al. (20) described the laser-assisted rapid maxillary expansion as LARME and stated in their in vivo study on 24 subjects aged $15.5-19$ years that there are more significant changes in most maxillofacial components in the laser group after the expansion phase. However, there were no significant differences with respect to retention or total treatment duration between the control and laser treatment groups. Laser applications may also be used in surgically assisted rapid palatal expansion. GaAlAs laser application accelerated bone regeneration in 13 individuals with the ages ranging from 18 to 33 and after the application of subtotal Le Fort I surgery-aided rapid maxillary expansion compared with the control group (21). The positive effects of laser applications on bone formation can be explained by rapid regeneration of blood vessels. In the study by Santiago et al. (22) on experimental dogs, soft laser (Photon Laser III) was used during sutural expansion, and they reported that laser use has stimulated the healing process during and after the expansion and contributed to suture reorganization and palatal bone osteogenesis. It is stated that with the histological sections obtained from sutural areas, the blood vessels in the laser-applied group had been distributed more uniformly and were of regular sizes similar to never opened suture, and this has affected the microcirculation and neoangiogenesis in a positive way. LLLT can also be used to accelerate the healing process after bone fractures, during mandibular distraction osteogenesis and osteoradionecrosis of the jaw, and for stimulating condylar growth (23-25).

According to the results of the study by Abtahi et al. (26) that examined the effects of LLLT on condylar growth during the mandibular advancement of rabbits, LLLT increased condylar growth during mandibular advancement with no change in articular cartilage and the thickness of fibrous tissue. According to the results of this study, functional treatment times can be shortened by LLLT.

\section{Orthodontic Debonding}

Laser energy provides less force application during the removal process of brackets by softening the adhesive resin material used to bond the brackets. Debonding operations with laser application are especially used effectively in ceramic brackets that have high adhesion with enamel way and in particular during the removal of ceramic brackets with the use of erbium-doped yttrium aluminum garnet (Er:YAG) laser scanning method that required lower shear bond strength than conventional methods and showed adhesive remnant index (ARI) scores between 2 and 3 (27). Laser energy may remove adhesive resin from the tooth surface through thermal softening, thermal ablation, and the effects of photoablation. The removal of ceramic brackets through Er:YAG laser is achieved with the effect of thermal soft- ening (27). There is a possibility of diffusion of the heat generated during laser-assisted debonding to the tooth structure even leading to pulpal damage. Although it is known that a temperature increase of $5.5^{\circ} \mathrm{C}$ in pulpal cavity leads to pulpal necrosis, studies showed that the diode laser with either $1 \mathrm{~W}$ or $3 \mathrm{~W}$ power for $3 \mathrm{~s}$ is effective in debonding the ceramic brackets without any detrimental effect on the pulp or mechanical properties of the enamel, whereas laser applications that reduce the bond strength of brackets did not cause a significant increase in pulpal cavity temperature (28). Er:YAG laser application with water cooling appeared to be a safer option by reducing resin shear bond strength and reducing the likelihood of intrapulpal temperature increase while debonding ceramic brackets (29). According to Dostalova et al. (30), the brackets were removed easily after the Er:YAG laser irradiation and temperature increase was limited for both ceramic and metal brackets; in addition, scanning electron microscopy (SEM) investigation has confirmed less damage of the enamel than non-irradiated samples. Mundethu et al. (31) used Er:YAG laser irradiation for debonding ceramic brackets with a single laser pulse and stated that the debonding process is in the majority of cases due to thermomechanical ablation in the superficial part of the adhesive layer and no additional force is necessary to remove the bracket from the tooth. SEM and light microscopy showed no damages to the enamel surface.

\section{Etching Procedures}

Following Buonocuore (32) using $85 \%$ of phosphoric acid to prepare the enamel's surface before direct bonding in 1955, etching with acid method in preparing the enamel surface is the most frequently used method nowadays. According to some researchers, etching of the enamel surface with chemical methods have disadvantages, such as demolition of inorganic material of enamel structure and creating a more vulnerable surface against carries attacks (33). Following the report that laser systems may remove smear layer, many laser systems have been used for etching of the enamel surface. Especially in orthodontic practice, the laser etching of the enamel has become attractive in recent years because of the user-friendly procedure and the occurrence of acid-resistant enamel surfaces after laser etching. The process of bracket bonding to the ceramic surface process is a matter of great importance in orthodontic patients with prosthetic restorations or aged composite or amalgam restorations in the mouth. In recent years, laser use on the etching of amalgam surface as in the preparation of all kinds of enamel surface has gained popularity. In a previous study, amalgam surface etching with Er,Cr:YSGG laser was compared to sandblasting technique, and the shear bonding strength of stainless steel brackets coated with laser-applied amalgam surface has been remarkably greater than those of the sandblasted group (34). In an in vi-tro study that was aimed to evaluate the shear bond strength of metal brackets to microhybrid composite restorations after four different surface preparation techniques (1-etching, 2-sand-blasting, 3- grinding, and 4-CO2 laser irradiation), it was concluded that surface preparation by sandblasting and $\mathrm{CO} 2$ laser pro-vides clinically acceptable results with regard to bond strength and ARI score; however, grinding and acid etching failed to produce the same results (35). 
Low-energy (80 mJ) Er:YAG laser levels are supposed to decrease demineralization, as shown by calcium and phosphorous measurements from the tooth surface (36). Lasmar et al. showed that Er:YAG laser causes less reduction in calcium oxide and phosphorus pentoxide $\left(\mathrm{P}_{2} \mathrm{O}_{5}\right)$ levels than acid etching. This reached significant levels in the $\mathrm{P}_{2} \mathrm{O}_{5}$ concentration, suggesting that the use of Er:YAG laser caused less demineralization than acid etching and white spot lesion formation (37). However, according to the findings by Cokakoglu et al. (38), the idea that laser etching might create remineralization microspaces by trapping free ions was rejected, and they indicated that different Er:YAG laser parameters of $1 \mathrm{~W}(100 \mathrm{~mJ}$ and $10 \mathrm{~Hz})$ or $2 \mathrm{~W}(200 \mathrm{~mJ}$ and $10 \mathrm{~Hz})$ for enamel conditioning cannot prevent enamel demineralization when using different adhesives.

According to Sallam et al. (39), it has been shown that there was no significant difference between the mean of shear bond strength and the etched groups, and it was concluded that the laser-etched group (1.5 W/15 Hz/Er:YAG laser) resulted in clinically accepted bond strength and could be an alternative to conventional acid etching. However, in another study (40), although high shear bonding strength has been obtained with Er:YAG laser-irradiated tooth samples prior to bonding, it was reported that enamel surfaces have been highly damaged during removal and so the acid etching method and single-step etching (self-etch) can be both used more safely in orthodontic bracket bonding.

\section{Laser-Assisted Polymerization}

Owing to the developments in orthodontic bonding materials, reducing the time spent during the attachment of orthodontic bonding is important for clinical success. The most common type of laser used for polymerization is argon laser. The active medium of argon laser is argon gas and in gated-pulse mode emits a visible blue and blue-green light via fiber optic tip with $488 \mathrm{~nm}$ and $514 \mathrm{~nm}$ in continuous wavelength (41). Recently, argon laser use is shown to be faster and more reliable than the conventional light-hardening method and light-emitting diode (LED) as an effective method in composite resin polymerization. It has been found that argon laser use in fluoride-released pit-fissure sealants polymerization provides a high degree of protection against cariogenic changes compared with visible light and LED polymerization (41). In a systematic review that the study protocol was based on the PRISMA statement, 20 studies were included, and according to the results, $\mathrm{CO}_{2}, \mathrm{Er}: \mathrm{YAG}$, and $\mathrm{Nd}$ :YAG are the most common lasers in using ceramic brackets in orthodontics. The use of laser is an effective method in different aspects of bonding procedures for ceramic brackets, such as bonding, debonding, rebonding, and the elimination of the remaining composite on the tooth surface (42).

\section{Mini-implant stability}

Mini-implants have been successfully used for orthodontic anchorage in many studies. However, mini-implant failure rate has been found to be between $11 \%$ and $30 \%$ (43). The rate of mini-implant failure affects the orthodontist's decision if he might use mini-implant or not in orthodontic daily practice. Despite all the advantages, mini-implants may loosen, and mo- bility can increase and at the end may fail during the treatment process. It has been reported that low-dose laser and LED photobiomodulation applications have positive effects on miniscrew stability. Pinto et al. (44) examined the effect of LLLT on the mini-implants and found that fast loading of $200 \mathrm{~g}$ has been applied on 32 mini-implants that are placed on rabbit tibias. LLLT has been applied for 21 days, and at the end, it was found that this application has significantly enhanced the implant stability. Although in an another split-mouth randomized clinical trial that involved 15 subjects with a mean age of $20.9( \pm 3.4)$ years who required extraction of the maxillary first premolar teeth and mini-implant-supported canine retraction, a diode laser with a wavelength of $940 \mathrm{~nm}$ at $0,7,14$, and 21 days after mini-implant placement was used in experimental sides. Mini-implant stability was measured using resonance frequency analysis at $0,1,2,3$, $4,6,8$, and 10 weeks after implant placement; however, according to the results, there were significant difference between the groups for 3-10 weeks and no difference for the first weeks over a 10-week period, and there were no differences in mini-implant stability. At the end, LLLT cannot be recommended as a clinically useful adjunct to promoting mini-implant stability during canine retraction (45).

\section{Soft Tissue Procedures}

In many stages of orthodontic treatment, soft tissue incisions or augmentations may be needed. Laser-assisted incisions have so many advantages during the surgical procedures, such as topical anesthesia is sufficient most of the time before laser intervention, the closure of blood vessels and lymphatic, more clean and clear field of view, no sutural requirement, less bleeding and edema in the postoperative period, and increased patient satisfaction (46). The areas of use of laser methods in soft tissue surgery in orthodontics include bonding preparation of teeth that the eruption has not been completed, removal of soft tissue on impacted canines and to do bonding in the same session, removal of excess tissue formed following the closure of large diastemas, bonding of second molar teeth by the removal of surround operculum, removal of hypertrophic and inflamed gingival tissues formed as a result of poor oral care, treatment of aphthous ulcers, correction of hyperpigmentation and crown lengthening by gingiva and shaping, and removal of high frenulum attachments (47). To et al. (48) compared the efficiency of laser-assisted gingivectomy (test group) and non-surgical periodontal therapy (control group) during fixed orthodontic treatment on patients with gingival hyperplasia. This comparison was made with the evaluation of five periodontal parameters (plaque index, gingival index, bleeding in probing, pocket depth, and gingival growth index), and as a result, a significant improvement was observed in both the test group and control group, and in the early stages of treatment for gingival index, pocket depth, and gingival growth parameters, more significant level of improvement was found in the test group.

\section{Laser-Assisted Circumferential Supracrestal Fiberotomy}

Long-term treatment stability in orthodontic treatment has always been an issue that needed to be focused on. One of the major reasons for the occurrence of relapse after orthodontic tooth movement is an the elastic supracrestal gingival fibril 
network (49). While collagenous fibers complete their reorganizations within 4-6 months, elastic supracrestal fibrils remodel slowly and are capable of generation of enough force to move the teeth even after 1 year after the completion of orthodontic treatment (42). In a randomized controlled clinical trial that compared the tendency of mandibular incisor's rotational relapse after conventional circumferential supracrestal fiberotomy (CSF) with Er,Cr:YSGG laser-aided CSF, it was concluded that laser-aided CSF in 1 month was as effective in reducing rotational relapse tendency of mandibular incisor teeth as conventional CSF and also probing depth, clinical crown height, and experienced pain levels exhibited negligible differences between the groups (50). According to the result of the study by Kim et al. (51), evaluating the effects of laser-assisted CSF and LLLT on the relapse of rotating teeth on test the dogs, laser-assisted CSF reduced the relapse when used on rotated teeth and support and did not cause any damage on periodontal structures, but LLLT application on rotated teeth increased the tendency of relapse without retainer. In a systematic review that aimed to evaluate the efficacy of LLLT on relapse of corrected tooth rotations, it was concluded that the effect of LLLT on relapse of corrected tooth rotations is related to energy density, and that low-energy density appears to incerase relapse, whereas high-energy density may reduce the relapse (52).

\section{Laser Scanning Systems}

Laser scanning systems can be used as soft tissue scanner, and three-dimensional (3D) images can be created using various techniques. The images created using this technique can be used for the publication of normative population data, to evaluate the results of treatment in advance for cross-sectional changes in growth, and to assess the treatment of the head and neck areas with or without surgery. 3D orthodontic scanning pattern done with laser scanning is a reliable method in arch-width and arch-length measurements on dental casts (53).

Many measurements and evaluations can be done on the models with laser scanning, including surface, area, and millimetric measurements. Noninvasive systems such as stereophotogrammetry can produce a 3D surface model from multiple viewpoints in a synchronized manner with a short capture time and clinically acceptable accuracy (54). Although the successful use of stereophotogrammetry has been reported for facial scanning, laser facial scanning is an alternative technique to stereophotogrammetry and has been successfully introduced into the workflow for making facial measurements and roducing facial protheses $(55,56)$. As with stereophotogrammetry, laser scanning of deeper regions and undercuts of face is limited by the separation of the laser-line generator and the receptor camera (55). In addition, some facial laser scanning systems will require the patient to remain motionless for a prolonged time which could further limit data acquisition (57).

\section{Welding Processes in Orthodontics}

Laser welding is one of the very recent yet versatile techniques used in dentistry, which is capable of manufacturing good quality weld joints with remarkable consistency. In addition, there are many ways for welding, such as soldering, resistance (spot) welding, plasma (torch) welding, and single pulse tungsten inert gas welding (4). The primary use of industrial lasers is to ensure the fusion of two metals without welding agents. It has been stated that other than laser use in the intraoral field, laser use in laboratory procedures are stronger than bonding with solder-ing material. Laser welding devices allow for welding on ortho-dontic devices in many different ways without soldering agents (58). Thus, heterogenetic orthodontic wires made of metal alloys of different components can be generated (59). Laser welding devices have advantages by making possible to manufacture the components of devices to be used in orthodontics, ensur-ing more durable connection than conventional welding agents (58). However, the laser devices can also be used in the intraoral environment. Studies showed that the lasers are biologically harmless for the periodontal tissues adjacent the laser welded ares, alveolar bone, and pulp tissue and have no thermal effect (60).

\section{CONCLUSION}

Laser system has far been the latest addition among these technologies that clearly have made an exceptional impact because of its minimal side effects, high precision level, and biocompatibility. There are many laser types determined for dental use, and laser systems have a wide range of applications in the fields of orthodontics and dentistry. Laser systems may be an exceptional modality of orthodontic treatment for many clinical conditions when used effectively. Although lasers have many advantages, it is important to determine the effective laser type and wavelength to meet all requirements in both soft and hard tissues, and the orthodontist should consider some points before using the laser that includes relatively high cost of the devices, needs additional education (especially in basic physics), every wavelength has different properties, and needs implementation of safety measures. In many areas of orthodontics, there are different types of lasers that can be used, but hence there is no single laser type that can meet all requirements in both hard and soft tissues; in routine practice, the orthodontist should analyze well for what purpose to use the system. In addition, in the literature, even if the effectiveness of soft tissue laser applications is generally indicated, there are conflicting results in applications, such as accelerating tooth movement, hard tissue laser applications, reducing relapse, etching operations, and mini-implant stability. Further randomized controlled studies with larger sample size are required to clarify these controversial results regarding the effectiveness of laser systems in orthodontic applications.

Peer-review: Externally peer-reviewed.

Author Contributions: Supervision - K.K.D., G.K.; Design - K.K.D., G.K. ; Data Collection and/or Processing - K.K.D., G.K.; Analysis and/or Interpretation - K.K.D., G.K.; Literature Search - K.K.D.; Writing Manuscript - K.K.D.; Critical Review - K.K.D., G.K.

Conflict of Interest: The authors have no conflict of interest to declare.

Financial Disclosure: The authors declared that this study has received no financial support. 


\section{REFERENCES}

1. Coluzzi DJ. Fundamentals of dental lasers: science and instruments. Dental Clinics. 2004; 48: 751-70. [CrossRef]

2. Frentzen $M$, Koort $H$. Lasers in dentistry: new possibilities with advancing laser technology? Int Dental J 1990; 40:3 23-32.

3. Coluzzi DJ. An Overview of Lasers in Dentistry. 2011.

4. Perveen A, Molardi C, Fornaini C. Applications of laser welding in dentistry: a state-of-the-art review. Micromachines (Basel) 2018; 9: pii: E209. doi: 10.3390/mi9050209. [CrossRef]

5. Genc G, Kocadereli I, Tasar F, Kilinc K, El S, Sarkarati B. Effect of low-level laser therapy (LLLT) on orthodontic tooth movement. Lasers Med Sci 2013; 28: 41-7. [CrossRef]

6. Wigdor H, Abt E, Ashrafi S, Walsh JT. The effect of lasers on dental hard tissues. J Am Dent Assoc 1993; 124: 65-70. [CrossRef]

7. Romanos GE. Clinical applications of the Nd: YAG laser in oral soft tissue surgery and periodontology. J Clin Laser Med Surg 1994; 12: 103-8. [CrossRef]

8. Guram G, Reddy RK, Dharamsi AM, Ismail PMS, Mishra S, Prakashkumar MD. Evaluation of low-level laser therapy on orthodontic tooth movement: a randomized control study. Contemp Clin Dent 2018; 9: 105-9.

9. Alazzawi MMJ, Husein A, Alam MK, Hassan R, Shaari R, Azlina A, et al. Effect of low level laser and low intensity pulsed ultrasound therapy on bone remodeling during orthodontic tooth movement in rats. Prog Orthod 2018; 19: 10. doi: 10.1186/s40510-0180208-2. [CrossRef]

10. AlSayed Hasan MMA, Sultan $K$, Hamadah O. Low-level laser therapy effectiveness in accelerating orthodontic tooth movement: A randomized controlled clinical trial. Angle Orthod 2016; 87: 499-504. [CrossRef]

11. Fujita S, Yamaguchi M, Utsunomiya T, Yamamoto H, Kasai K. Lowenergy laser stimulates tooth movement velocity via expression of RANK and RANKL. Orthod Craniofac Res 2008; 11: 143-55. [CrossRef]

12. Long $H$, Pyakurel $U$, Wang $Y$, Liao L, Zhou $Y$, Lai W. Interventions for accelerating orthodontic tooth movement: a systematic review. Angle Orthod 2012; 83: 164-71. [CrossRef]

13. Lim H-M, Lew KK, Tay DK. A clinical investigation of the efficacy of low level laser therapy in reducing orthodontic postadjustment pain. Am J Orthod Dentofacial Orthop 1995; 108: 614-22. [CrossRef]

14. Yamaguchi M, Hayashi M, Fujita S, Yoshida T, Utsunomiya T, Yamamoto $\mathrm{H}$, et al. Low-energy laser irradiation facilitates the velocity of tooth movement and the expressions of matrix metalloproteinase-9, cathepsin $\mathrm{K}$, and alpha ( $\mathrm{v}$ ) beta (3) integrin in rats. Eur J Orthod 2010; 32: 131-9. [CrossRef]

15. Marini I, Bartolucci ML, Bortolotti F, Innocenti G, Gatto MR, Bonetti GA. The effect of diode superpulsed low-level laser therapy on experimental orthodontic pain caused by elastomeric separators: a randomized controlled clinical trial. Lasers Med Sci 2015; 30: 35-41. [CrossRef]

16. Wu S, Chen Y, Zhang J, Chen W, Shao S, Shen H, et al. Effect of low-level laser therapy on tooth-related pain and somatosensory function evoked by orthodontic treatment. Int J Oral Sci 2018; 10: 22. doi: 10.1038/s41368-018-0023-0. [CrossRef]

17. Qamruddin I, Alam MK, Abdullah H, Kamran MA, Jawaid N, Mahroof V. Effects of single-dose, low-level laser therapy on pain associated with the initial stage of fixed orthodontic treatment: A randomized clinical trial. Korean J Orthod 2018; 48: 90-7. [CrossRef]

18. Eslamian L, Borzabadi-Farahani A, Hassanzadeh-Azhiri A, Badiee MR, Fekrazad R. The effect of 810-nm low-level laser therapy on pain caused by orthodontic elastomeric separators. Lasers Med Sci 2014; 29: 559-64. [CrossRef]
19. Cepera F, Torres FC, Scanavini MA, Paranhos LR, Capelozza Filho L, Cardoso MA, et al. Effect of a low-level laser on bone regeneration after rapid maxillary expansion. Am J Orthod Dentofacial Orthop 2012;141: 444-50. [CrossRef]

20. Moawad SG, Bouserhal J, Al-Munajed MK. Assessment of the efficiency of Erbium-YAG laser as an assistant method to rapid maxillary expansion: An in vivo study. Int Orthod 2016; 14: 462-75. [CrossRef]

21. Angeletti P, Pereira MD, Gomes HC, Hino CT, Ferreira LM. Effect of low-level laser therapy (GaAlAs) on bone regeneration in midpalatal anterior suture after surgically assisted rapid maxillary expansion. Oral Surg Oral Med Oral Pathol Oral Radiol Endod 2010; 109: e38-46. [CrossRef]

22. Santiago VC, Piram A, Fuziy A. Effect of soft laser in bone repair after expansion of the midpalatal suture in dogs. Am J Orthod Dentofacial Orthop 2012; 142: 615-24. [CrossRef]

23. Ribeiro $G H$, Minamisako $M C$, Rath IBdS, Santos $A M B$, Simões $A$, Pereira KCR, et al. Osteoradionecrosis of the jaws: case series treated with adjuvant low-level laser therapy and antimicrobial photodynamic therapy. J Appl Oral Sci 2018; 26: doi: 10.1590/1678-77572017-0172. [CrossRef]

24. Gurler G, Gursoy B. Investigation of effects of low level laser therapy in distraction osteogenesis. J Stomatol Oral Maxillofac Surg 2018; 119: 469-76. [CrossRef]

25. Okşayan R, Sökücü O, Üçüncü N. The effects of low-level laser therapy on condylar growth with a mandibular advancement appliance in rats. Photomed Laser Surg 2015; 33: 252-7. [CrossRef]

26. Abtahi M, Poosti M, Saghravanian N, Sadeghi K, Shafaee H. The effect of low level laser on condylar growth during mandibular advancement in rabbits. Head Face Med 2012; 8: 4. doi: 10.1186/1746160X-8-4. [CrossRef]

27. Oztoprak MO, Nalbantgil D, Erdem AS, Tozlu M, Arun T. Debonding of ceramic brackets by a new scanning laser method. Am J Orthod Dentofacial Orthop 2010; 138: 195-200. [CrossRef]

28. Sinaee N, Salahi S, Sheikhi M. Evaluation of the effect of diode laser for debonding ceramic brackets on nanomechanical properties of enamel. Dent Res J (Isfahan) 2018; 15: 354-60. [CrossRef]

29. Nalbantgil D, Tozlu M, Oztoprak MO. Pulpal thermal changes following Er-YAG laser debonding of ceramic brackets. ScientificWorldJournal 2014; 2014: doi: 10.1155/2014/912429. [CrossRef]

30. Dostálová $T j$, Remeš $M$, Jelínková $H$, Šulc J, Němec $M$, Vyhlídal D, editors. Er: YAG laser metal and ceramic bracket debonding. Lasers in Dentistry XXIl; 2016: International Society for Optics and Photonics. [CrossRef]

31. Mundethu AR, Gutknecht N, Franzen R. Rapid debonding of polycrystalline ceramic orthodontic brackets with an Er: YAG laser: an in vitro study. Lasers Med Sci 2014; 29: 1551-6. [CrossRef]

32. Buonocore MG. A simple method of increasing the adhesion of acrylic filling materials to enamel surfaces. J Dent Res 1955; 34: 84953. [CrossRef]

33. Corpas-Pastor L, Villalba Moreno J, de Dios Lopez-Gonzalez Garrido J, Pedraza Muriel V, Moore K, Elias A. Comparing the tensile strength of brackets adhered to laser-etched enamel vs. acid-etched enamel. J Am Dent Assoc 1997; 128: 732-7. [CrossRef]

34. Oskoee PA, Kachoei M, Rikhtegaran S, Fathalizadeh F, Navimipour EJ. Effect of surface treatment with sandblasting and $\mathrm{Er}, \mathrm{Cr}$ : YSGG laser on bonding of stainless steel orthodontic brackets to silver amalgam. Med Oral Patol Oral Cir Bucal 2012; 17: e292-6. [CrossRef]

35. Zarif Najafi H, Mousavi M, Nouri N, Torkan S. Evaluation of the effect of different surface conditioning methods on shear bond strength of metal brackets bonded to aged composite restorations. Int Orthod 2019; 17: 80-8. [CrossRef] 
36. Cecchini RCM, Zezell DM, de Oliveira E, de Freitas PM, Eduardo CdP. Effect of Er: YAG laser on enamel acid resistance: Morphlogical and atomic spectrometry analysis. Lasers Surg Med 2005; 37: 366-72. [CrossRef]

37. Lasmar M, Reher V, Lalloo R, Reher P. Enamel demineralization and bracket bond strength when etching with acid and/or Er: YAG laser. Aust Dent J 2012; 57: 190-5. [CrossRef]

38. Çokakoğlu S, Nalçacı R, Üşümez S, Malkoç S. Effects of different combinations of Er: YAG laser-adhesives on enamel demineralization and bracket bond strength. Photomed Laser Surg 2016; 34: 164-70. [CrossRef]

39. Sallam RA, Arnout EA. Effect of Er: YAG laser etching on shear bond strength of orthodontic bracket. Saudi Med J 2018; 39: 922-7. [CrossRef]

40. Türköz Ç, Ulusoy Ç. Evaluation of different enamel conditioning techniques for orthodontic bonding. Korean J Orthod 2012; 42: 32 8. [CrossRef]

41. Das U, Prashanth S. A comparative study to evaluate the effect of fluoride releasing sealant cured by visible light, argon laers, and light emitting diode curing units: An in vitro study. J Indian Soc Pedod Prev Dent 2009; 27: 139-44. [CrossRef]

42. Matini NS, Motabar M. Current Status for Laser-Assisted Orthodontics in the Application of Ceramic Brackets. J Lasers Med Sci 2018; 9.

43. Kravitz ND, Kusnoto B. Risks and complications of orthodontic miniscrews. Am J Orthod Dentofacial Orthop 2007; 131(4 Suppl): S43-51. [CrossRef]

44. Pinto MR, dos Santos RL, Pithon MM, de Souza Araújo MT, Braga JPV, Nojima LI. Influence of low-intensity laser therapy on the stability of orthodontic mini-implants: a study in rabbits. Oral Surg Oral Med Oral Pathol Oral Radiol 2013; 115: e26-30. [CrossRef]

45. Abohabib AM, Fayed MM, Labib AH. Effects of low-intensity laser therapy on the stability of orthodontic mini-implants: a randomised controlled clinical trial. J Orthod 2018; 45: 149-56. [CrossRef]

46. Seifi M, Matini NS. Laser surgery of soft tissue in orthodontics: Review of the clinical trials. J Lasers Med Sci 2017; 8(Suppl 1): S1-6. [CrossRef]

47. Kulkarni RB, Misal A, Mishra R. Soft tissue diode laser in orthodontics. Int J Appl Dent Sci 2017; 3: 91-4.

48. To TN, Rabie AB, Wong RW, McGrath CP. The adjunct effectiveness of diode laser gingivectomy in maintaining periodontal health during orthodontic treatment. Angle Orthod 2013; 83: 43-7. [CrossRef]

49. Edwards JG. A study of the periodontium during orthodontic rotation of teeth. Am J Orthod 1968; 54: 441-61. [CrossRef]

50. Miresmæili AF, Mollabashi V, Gholami L, Farhadian M, Rezaei-Soufi L, Javanshir B, et al. Comparison of conventional and laser-aided fiberotomy in relapse tendency of rotated tooth: A randomized controlled clinical trial. Int Orthod 2019; 17: 103-13. [CrossRef]

51. Kim SJ, Paek JH, Park KH, Kang SG, Park YG. Laser-aided circumferential supracrestal fiberotomy and low-level laser therapy effects on relapse of rotated teeth in beagles. Angle Orthod 2010; 80: 385-90. [CrossRef]

52. Meng M, Yang M, Lv C, Yang Q, Yang Z, Chen S. Effect of low-level laser therapy on relapse of rotated teeth: A systematic review of human and animal study. Photomed Laser Surg 2017; 35: 3-11. [CrossRef]

53. Erten O, YIlmaz BN. Three-Dimensional Imaging in Orthodontics. Turk J Orthod 2018; 31: 86-94. [CrossRef]

54. Sabol JV, Grant GT, Liacouras P, Rouse S. Digital image capture and rapid prototyping of the maxillofacial defect. J Prosthodont 2011; 20: 310-4. [CrossRef]

55. Cheah CM, Chua CK, Tan KH, Teo CK. Integration of laser surface digitizing with CAD/CAM techniques for developing facial prostheses. Part 1: design and fabrication of prosthesis replicas. Int J Prosthodont 2003; 16: 435-41.

56. Ciocca L, Mingucci R, Gassino G, Scotti R. CAD/CAM ear model and virtual construction of the mold. J Prosthet Dent 2007; 98: 339-43. [CrossRef]

57. Jablonski RY, Osnes CA, Khambay BS, Nattress BR, Keeling AJ Accuracy of capturing oncology facial defects with multimodal image fusion versus laser scanning. J Prosthet Dent 2019; 122: 333-8. [CrossRef]

58. Hurt AJ. Digital technology in the orthodontic laboratory. Am J Orthod Dentofacial Orthop 2012; 141: 245-7. [CrossRef]

59. Watanabe E, Stigall G, Elshahawy W, Watanabe I. Deflection load characteristics of laser-welded orthodontic wires. Angle Orthod 2011; 82: 698-702. [CrossRef]

60. Fornaini C, Bertrand C, Rocca J, Mahler P, Bonanini M, Vescovi P, et al. Intra-oral laser welding: an in vitro evaluation of thermal increase. Lasers Med Sci 2010; 25: 473-7. [CrossRef] 